\title{
1. COOLING HISTORIES OF LAVAS FROM SEROCKI VOLCANO ${ }^{1}$
}

\author{
Timothy L. Grove²
}

\begin{abstract}
A dynamic crystallization study was undertaken to provide a framework for linking the textural variations observed in the Hole 648B lavas with the size and morphology of cooling units inferred from drilling and submersible observation. The textures produced in cooling rate experiments carried out using a Serocki lava (ALV-1690-20) are comparable to the groundmass textural characteristics of lavas from Serocki volcano. The results of the dynamic crystallization study provide a quantitative link between texture, cooling rate, and eruption temperature. The maximum half-width of cooling units estimated from textural characteristics is on the order of $3 \mathrm{~m}$, a value consistent with constraints from drilling and submersible observation. Textural characteristics indicate that the temperature from which cooling began was slightly above the liquidus. The relation between cooling rate and texture are also tested on a drill core sample of basalt of similar composition from a 9-m-thick flow in DSDP Hole 396B.
\end{abstract}

\section{INTRODUCTION}

The combination of drilling carried out in Hole 648B and observations of the site by the submersible Alvin provide a unique opportunity for understanding the eruption and cooling history of Serocki volcano. This small volcanic feature, about $800 \mathrm{~m}$ in diameter, $60 \mathrm{~m}$ high, with a flat summit and steep sides, contains a central collapsed caldera about $250 \mathrm{~m}$ in diameter and $60 \mathrm{~m}$ deep. Hole $648 \mathrm{~B}$ was drilled on the rim of the summit plateau and penetrated the shield of Serocki volcano to a depth of about $50 \mathrm{~m}$. Core recovered during drilling in 648B was interpreted to have sampled three stratigraphic units within the shield. The first unit is pillow lavas which comprise the upper $30 \mathrm{~m}$ of drill core. Below the pillow lavas is a vesicular basalt unit about $3 \mathrm{~m}$ thick, which may represent the top of a ponded or massive lava flow. The third unit occurs in the lower $17 \mathrm{~m}$ and consists of a massive holocrystalline basalt. This paper discusses the textures in Serocki lavas and estimates flow thicknesses in the lowermost massive unit. Submersible observations in the caldera and on the eastern side of Serocki (Humphris et al., 1986) indicate that the upper $30 \mathrm{~m}$ is composed of bulbous pillow lavas $1-2 \mathrm{~m}$ in diameter. Below this the walls are covered by talus. The floor of the caldera consists of highly fractured lava flows, which may represent the older volcanic material on which Serocki volcano was built.

\section{EXPERIMENTS}

Sample ALV-1690-20 of Serocki lava was collected by submersible Alvin from the pillow lavas of the upper $30 \mathrm{~m}$ of Serocki volcano. This sample consists of fresh glassy to aphyric pillow buds containing $<2 \%$ phenocrysts $(1-3 \mathrm{~mm})$ of plagioclase. The fresh, glassy parts of the pillows were used as starting material in the 1-atm cooling rate experiments, and were reduced to powder by grinding in a SPEX shatterbox for $3 \mathrm{~min}$. The resulting powder was pressed into $0.08-0.10 \mathrm{~g}$ pellets using elvanol as a binder. An oxygen-natural gas torch was used to sinter these pellets to 0.008 -in. PtFe alloy loops that were fabricated to minimize $\mathrm{Fe}$ exchange between the loop and silicate sample (Grove, 1981). Experiments were

\footnotetext{
${ }^{I}$ Detrick, R., Honnorez, J., Bryan, W. B., Juteau, T., et al., 1990. Proc. ODP, Sci. Results, 106/109: College Station, TX (Ocean Drilling Program).

2 Department of Earth, Atmospheric and Planetary Sciences, Massachusetts Institute of Technology, Cambridge, MA 02139.
}

carried out in Deltech DT31VT quenching furnaces in a $\mathrm{CO}_{2}-\mathrm{H}_{2}$ gas atmosphere maintained at the quartz-fayalitemagnetite buffer, using gas flow rates of $0.1 \mathrm{~mL} / \mathrm{s}$. Oxygen fugacity was monitored using $\mathrm{ZrO}_{2}-\mathrm{CaO}$ electrolyte cells calibrated at the $\mathrm{Fe}-\mathrm{FeO}, \mathrm{Cu}-\mathrm{Cu}_{2} \mathrm{O}$, and $\mathrm{Ni}-\mathrm{NiO}$ buffers. Temperature was monitored using $\mathrm{Pt}-10 \mathrm{Rh}$ thermocouples calibrated against the melting points of $\mathrm{NaCl}, \mathrm{Au}$, and $\mathrm{Pd}$ on the IPTS 1968 temperature scale (Biggar, 1972). A linear cooling rate was provided using Eurotherm 125 temperature programmers. The temperature programmer is wired into the thermocouple control circuit and adds a linear millivoltage signal to control temperature drop.

Cooling rate experiments (Table 1) were carried out by holding the sample at an initial temperature $\left(1196^{\circ} \mathrm{C}\right), 9^{\circ} \mathrm{C}$ below the 1-atm liquidus near the maximum temperature for the stability of olivine + plagioclase. The liquidus for ALV$1690-20$ at $1 \mathrm{~atm}$ is $1205^{\circ} \mathrm{C}$ (Grove et al., this volume). After 24 $\mathrm{hr}$ at this initial temperature, the sample was cooled to a subsolidus temperature, and the experiment was terminated by quenching into water.

In 1-atm wire loop experiments, the exchange of $\mathrm{Fe}$ between loop and silicate charge, and the loss of $\mathrm{Na}$ from the silicate charge by volatilization are two problems which can compromise the experimental results and make comparison with natural lava questionable. In these experiments both $\mathrm{Fe}$ loss and $\mathrm{Na}$ volatilization have been essentially eliminated, by using PtFe alloys, extremely low gas flow rates and "large" sample size (Tormey et al., 1987). A potential problem with cooling rate experiments is the extent to which the experiment duplicates nucleation and growth conditions that existed in nature. For the experimental analog to provide a valid estimate of the cooling process, the nucleation and growth processes must be identical. Lofgren et al. (1979) discuss some of the shortcomings of analog cooling rate studies, and it is clear that the conditions of the experiments were not identical to those present during crystallization on the seafloor. As discussed below, there are some systematic differences between textures in the lavas and experiments, which may result from differences between the nucleation and growth processes in nature and in the experiments.

\section{Textural characterization}

Experimental run products and Hole 648B samples were prepared as polished thin sections and examined by optical microscopy and by back-scattered electron imaging (BEI) on 
Table 1. Cooling rate experiments on basalt ALV-1690-20 from Serocki volcano.

\begin{tabular}{lccccc}
\hline Run \# & $\begin{array}{c}\mathrm{T}_{\text {initial }} \\
\left({ }^{\circ} \mathrm{C}\right)\end{array}$ & $\begin{array}{c}\text { Duration } \\
(\mathrm{hr})\end{array}$ & $\begin{array}{c}\text { Rate } \\
\left({ }^{\circ} \mathrm{C} / \mathrm{hr}\right)\end{array}$ & $\begin{array}{c}\mathrm{T}_{\text {final }} \\
\left({ }^{\circ} \mathrm{C}\right)\end{array}$ & $\begin{array}{c}\text { Plag width }^{\mathrm{a}} \\
(\mathrm{mm})\end{array}$ \\
\hline CR1 & 1194 & 23.1 & 9.5 & 876 & $0.042-0.072$ \\
CR2 & 1195 & 19.8 & 110 & 846 & $0.027-0.045$ \\
CR3 & 1196 & 20.8 & 2.0 & 822 & $0.078-0.11$ \\
\hline
\end{tabular}

a Plagioclase width is the average of 6-12 of the largest crystals in each thin section measured perpendicular to the $(010)$ crystal faces.

the JEOL 733 Superprobe at MIT. For both techniques the width of plagioclase dendrites perpendicular to the $(010)$ crystallographic orientation was used to quantitatively characterize groundmass texture (Table 2). With the BEI technique all groundmass plagioclases in a given image were measured and averaged. In the optical microscope only the largest plagioclases visible in the thin section were measured and averaged. The two techniques produce different results, the BEI measurements are representative of the size distribution of the entire groundmass plagioclase population (Cashman and Marsh, 1984) while the optical microscope technique is representative of the upper size range of the population. The optical microscope characterization is the same as the technique used in previous textural characterization studies (Walker et al., 1976; Grove and Walker, 1977; Walker et al., 1978; Grove, 1978), and the results from this method are used in making comparisons with previous studies.

\section{Textural characteristics of lavas}

The basalts recovered from Hole 648B are sparsely to moderately olivine-plagioclase phyric, containing on average about $2-4$ vol.\% phenocrysts and glomerocrysts $0.5-1.5 \mathrm{~mm}$ in size. The groundmass textures vary from glassy, variolitic, pilotaxitic, intergranular to subophitic. In the intergranular and subophitic samples the groundmass contains about $45 \%$ plagioclase, $42 \%$ augite, $5 \%$ oxides (titanomagnetite, ilmenite, and sulfide), and $1 \%-2 \%$ olivine. A dominant textural feature of the groundmass is defined by plagioclase size and shape. Plagioclase textures range from the hopper and swallowtail morphology typical of plagioclase in the groundmass of many ocean floor basalts (Bryan, 1972) to skeletal and dendritic. Augitic clinopyroxene ranges in texture from subequant to acicular to dendritic. Aphyric rocks with finer-grained groundmass show similar mineralogy and texture with glass becoming a more dominant constituent as texture grades from intersertal to intergranular to variolitic.

A subset of lavas with intergranular to subophitic groundmass textures was chosen from drill cores which sampled the lowermost massive stratigraphic unit in Serocki volcano; Cores 648B-15R and 648B-18R. Typical groundmass textures are shown in BEI in Figure 1, where increasing width of groundmass plagioclase measured perpendicular to the $(010)$ has been used to order lavas. Plagioclase in the groundmass shows either a variable or bimodal size distribution. In the finer grained samples the smaller plagioclase is skeletal to dendritic and the coarser plagioclase has a hopper to swallowtail morphology. In the coarser lava the groundmass plagioclase shows the hopper and swallowtail morphology over the entire size range.

\section{Textural characteristics of experiments}

The textures of the cooling rate experiments (Fig. 2) are comparable to the groundmass textures developed in the Serocki lavas. The texture of the $110^{\circ} \mathrm{C} / \mathrm{hr}$ experiment is an
Table 2. Groundmass plagioclase size in lavas from Serocki volcano sampled by drilling in Hole 648B.

\begin{tabular}{lccc}
\hline \multicolumn{1}{c}{ Sample } & $\begin{array}{c}\text { Plag width } \\
(\mathrm{mm})\end{array}$ & $\begin{array}{c}\text { Estimated cooling } \\
\left({ }^{\circ} \mathrm{C} / \mathrm{hr}\right)\end{array}$ & $\begin{array}{c}\text { Distance from } \\
\text { chill margin } \\
(\mathrm{cm})\end{array}$ \\
\hline $109-648 \mathrm{~B}-$ & & & \\
$15 \mathrm{R}-1,75-79 \mathrm{~cm}$ & 0.118 & 1 & 48 \\
$15 \mathrm{R}-1,92-94 \mathrm{~cm}$ & 0.085 & $2-5$ & $22-36$ \\
$15 \mathrm{R}-1,107-108 \mathrm{~cm}$ & 0.182 & $0.2-0.5$ & $70-111$ \\
$15 \mathrm{R}-1,119-122 \mathrm{~cm}$ & $0.247-0.30$ & $0.02-0.25$ & $100-300$ \\
$15 \mathrm{R}-1,136-138 \mathrm{~cm}$ & $0.184-0.210$ & $0.1-0.6$ & $65-160$ \\
$15 \mathrm{R}-1,146-148 \mathrm{~cm}$ & $0.171-0.245$ & $0.05-0.6$ & $90-225$ \\
$18 \mathrm{R}-1,32-34 \mathrm{~cm}$ & $0.20-0.273$ & $0.03-0.4$ & $140-290$ \\
\hline
\end{tabular}

a Plagioclase width is the average of 6-12 of the largest crystals in each thin section measured perpendicular to the (010) crystal faces.

exception, and is not similar to that found in the Serocki lavas. The texture of this experiment is microporphyritic with plagioclase as the microphenocryst and a skeletal to dendritic groundmass of plagioclase, olivine, augite, oxides set in glass. Plagioclase in this $110^{\circ} \mathrm{C} / \mathrm{hr}$ experiment has a size distribution that is distinctly bimodal. In the $10^{\circ} / \mathrm{hr}$ and $2^{\circ} \mathrm{C} / \mathrm{hr}$ experiments, the textures are intergranular to subophitic. Augitic pyroxene varies from dendritic and acicular in the $10^{\circ} \mathrm{C} / \mathrm{hr}$ run to subhedral and equant in the $2^{\circ} \mathrm{C} / \mathrm{hr}$ run. Plagioclase shows the elongate hopper to swallowtail morphology that is the dominant groundmass textural characteristic of the Serocki lavas. There is a notable difference in the plagioclase morphology of the experiments. Compared to the Serocki lavas the experimentally produced plagioclase laths are shorter in the direction of maximum elongation at a comparable (010) width. The textural characteristics of other groundmass constituents (titanomagnetite, ilmenite, sulfide, and glass) in the $10 \%$ hr and $3^{\circ} \mathrm{C} / \mathrm{hr}$ experiments are similar to those developed in the Serocki lavas.

\section{Experimental calibration of cooling rate}

Estimates of cooling rate can be obtained from textural characteristics, and an extensive literature exists on the use of textures to provide quantitative measures of cooling rates for lunar lavas (see Lofgren, 1980, for a review). One technique developed in the lunar cooling rate experiments is to use easily measured textural characteristics, like crystal size and abundance, to estimate cooling rate. If the temperature interval over which the texture records cooling rate can be inferred, then some simple heat conduction models can be applied to estimate magma body size (Winkler, 1949; Jaeger, 1957).

In a cooling lava, crystal nucleation and growth rates vary in response to changes in cooling rate as well as to changes in degree of undercooling. At high cooling rates (i.e. $>100^{\circ} \mathrm{C} / \mathrm{hr}$ ) nucleation rate is rapid, growth rate is slow, and the resulting texture consists of many small crystals. At slow cooling rates nucleation rate is slower, growth rates are faster, and fewer larger crystals grow. In addition, undercooling, defined as the equilibrium crystallization temperature of a mineral and the actual appearance temperature, increases as cooling rate increases. At large undercooling values dendritic and skeletal crystal morphologies develop, while "equilibrium" equant morphologies develop at small undercoolings. These effects have been described for several natural examples (Lofgren, 1980 ), and Kirkpatrick (1978) has described variation in crystal morphology and size near the chill margin of oceanic pillow lavas from Hole 396B.

In both lunar and meteorite cooling rate studies there is a strong correlation between cooling rate and plagioclase size and morphology (Walker et al., 1976; Grove and Walker, 


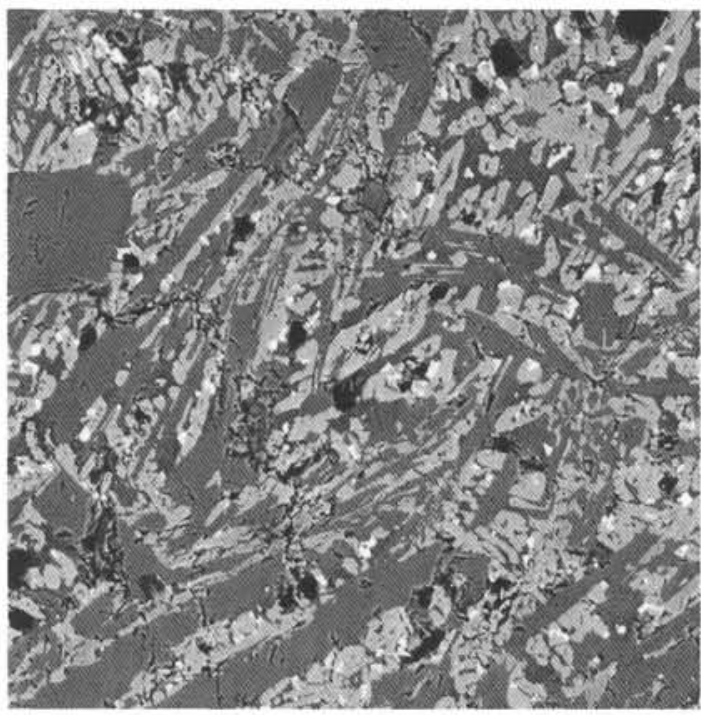

A

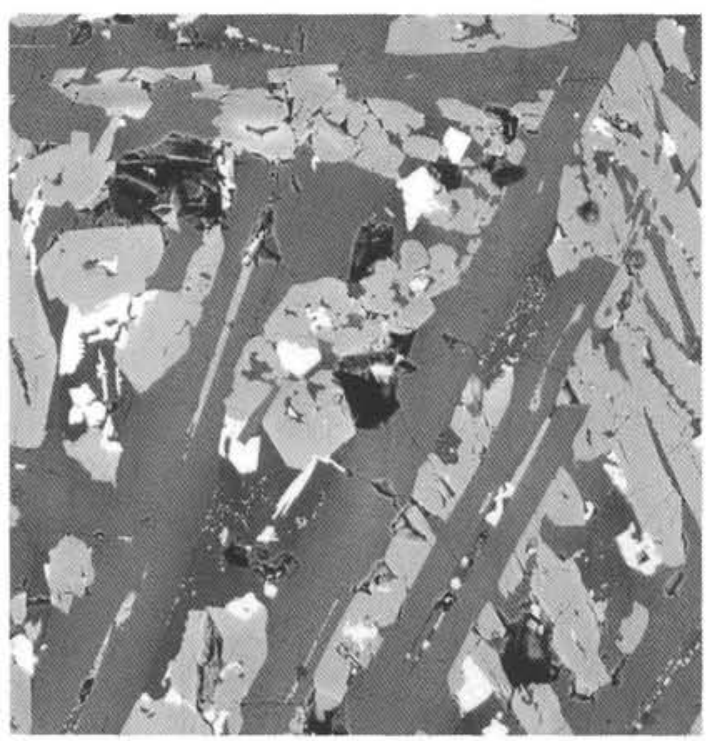

C

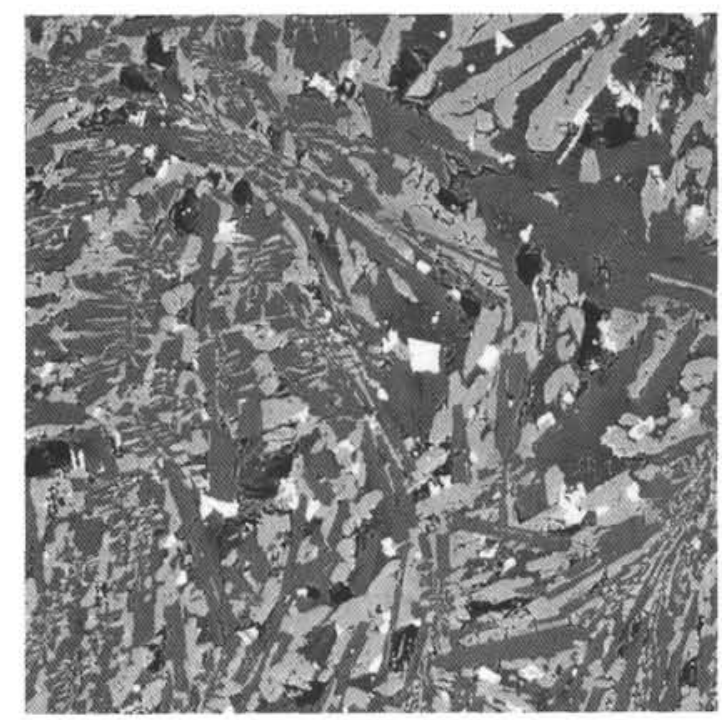

B

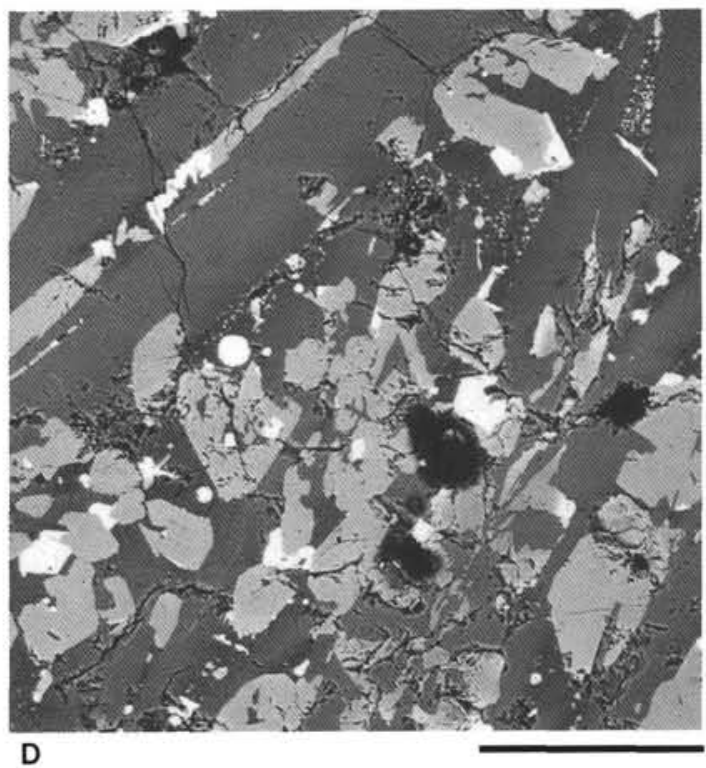

Figure 1. Back-scattered electron images of groundmass textures in lavas from Serocki volcano. Scale bar is $0.1 \mathrm{~mm}$, and magnification is the same for all photographs. A. $648 \mathrm{~B}-15 \mathrm{R}-1,75-79 \mathrm{~cm}$. B. $648 \mathrm{~B}-15 \mathrm{R}-1,92-94 \mathrm{~cm}$. C. 648B-15R-1, 107-108 cm. D. 648B-15R-1, 119-122 cm.

1977; Walker et al., 1978; Grove, 1978). In addition, the size and morphology of plagioclase crystals are strongly dependent on the temperature from which final cooling begins (Nabalek et al., 1978; Walker et al., 1978; Lofgren, 1983). Walker et al. (1978) crystallized Stannern, a eucrite basalt which is multiply saturated at its liquidus with pyroxene and plagioclase, and found a dependence of texture on both initial melting temperature $\left(\mathrm{T}_{\text {init }}\right)$ and cooling rate. At $\mathrm{T}_{\text {init }}>$ plagioclase appearance temperature, plagioclase morphology is an elongate, hollow variant of the swallowtail form. At $\mathrm{T}_{\text {init }}<$ plagioclase appearance temperature, the plagioclase grows as a stubby, equant variant of the swallowtail form in an intergranular to subophitic groundmass.

The dependence of plagioclase size on cooling rate for the Serocki experiments is shown in Figure 3A. For these Serocki experiments $T_{\text {init }}$ was $9^{\circ} \mathrm{C}$ below the liquidus and the liquid was multiply saturated with plagioclase and olivine. Also shown is the curve determined by Walker et al. (1978) for Stannern cooling rate experiments initiated $5^{\circ} \mathrm{C}$ below the plagioclase appearance. The curves for these two multiply saturated basaltic compositions are strikingly similar.

In Figure $3 \mathrm{~B}$ are shown plagioclase size vs. cooling rate dependencies for Stannern and a Luna 24 ferrobasalt (Grove, 1978), which is multiply saturated with olivine and plagioclase at its liquidus. Both of these curves are for $\mathrm{T}_{\text {init }}>$ plagioclase appearance, and within the variability of sizes measured in each set of experiments the results overlap (see Grove, 1978, Fig. 5, and Walker et al., 1978, Fig. 7). The plagioclase size vs. cooling rate curve produced by Grove and Walker (1977) for an Apollo 15 quartz normative basalt for $\mathrm{T}_{\text {init }}>$ plagioclase appearance has a slope and intercept that is also nearly identical to the two studies plotted in Figure 3B. Note that the slope of the curves for $T_{\text {init }}>$ plagioclase appearance is steeper than the slope for $\mathrm{T}_{\text {init }}<$ plagioclase appearance. 


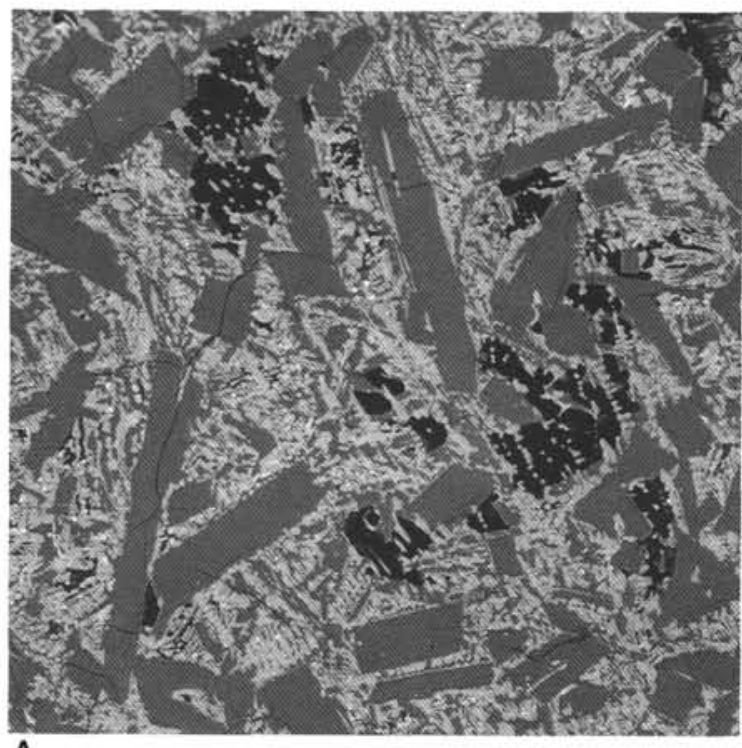

A
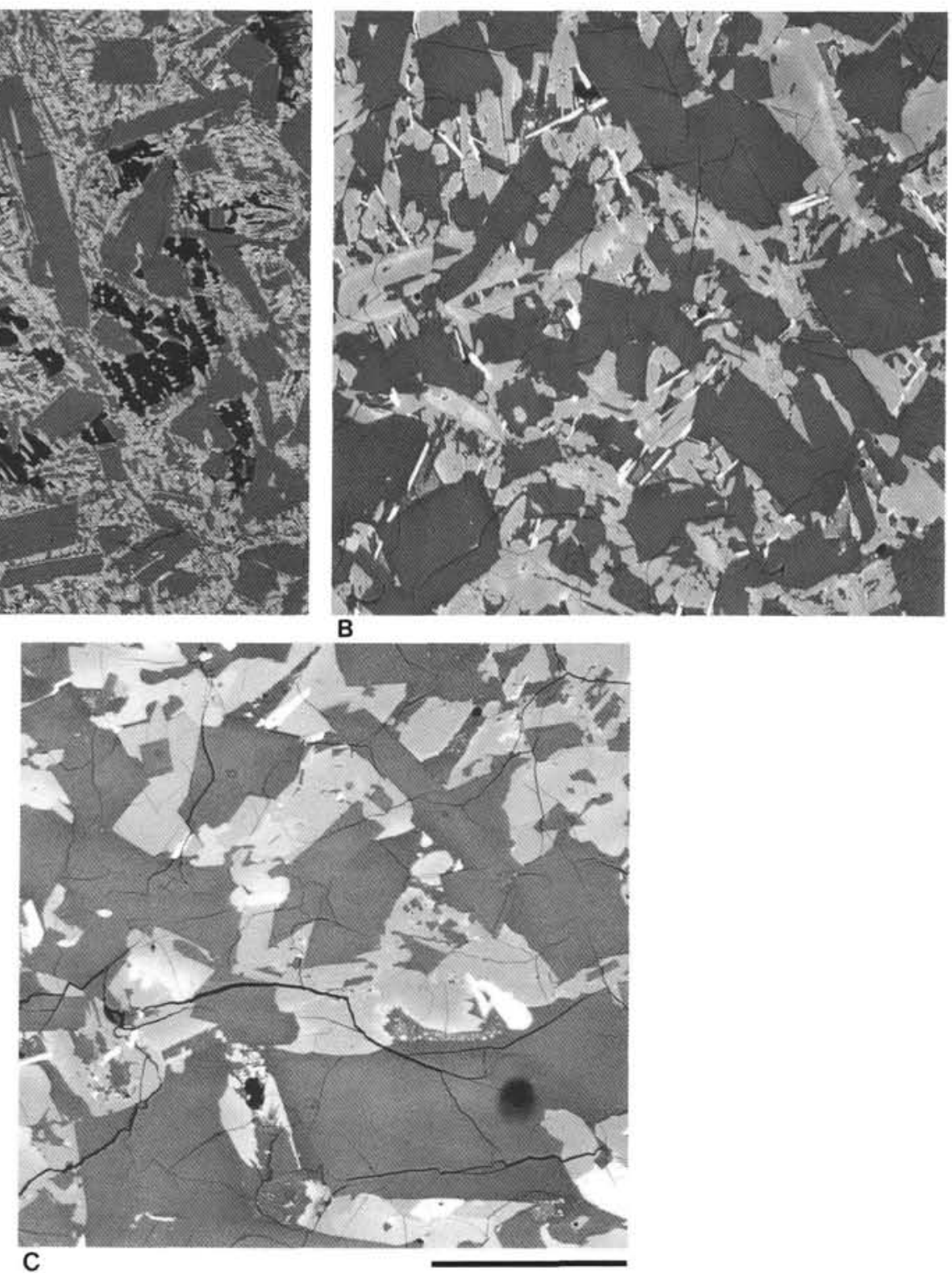

Figure 2. Back-scattered electron images of groundmass textures produced in cooling rate experiments on Serocki lava ALV-1690-20. Scale bar is $0.1 \mathrm{~mm}$, and magnification is the same for all photographs. A. $110^{\circ} \mathrm{C} / \mathrm{hr}$ cooling rate experiment. B. $10^{\circ} \mathrm{C} / \mathrm{hr}$ cooling rate experiment. C. $2^{\circ} \mathrm{C} / \mathrm{hr}$ cooling rate experiment.

The plagioclase size vs. cooling rate curves determined for Stannern and ALV-1690-20 (Fig. 3A) are similar, and the plagioclase size vs. cooling rate curves for three different basalt compositions, including Stannern, at $\mathrm{T}_{\text {init }}>$ plagioclase appearance (Fig. 3B) are also similar. Therefore, the simple functional relationship in Figure 3B for $\mathrm{T}_{\text {init }}>$ plagioclase appearance is assumed to be applicable to the Serocki lavas and is used to relate plagioclase size and cooling rate.

The curves in Figures $3 \mathrm{~A}$ and $3 \mathrm{~B}$ cross at an $\ln$ cooling rate value of 2 , and the curve for $T_{\text {init }}>$ plagioclase appearance is steeper. Thus, at any cooling rate $<7^{\circ} \mathrm{C} / \mathrm{hr}$, plagioclase will be larger if $T_{\text {init }}>$ plagioclase appearance, and smaller if $T_{\text {init }}<$ plagioclase appearance. In the following discussion, plagioclase size will be used to predict cooling rate, and the Serocki experimental curve and the Stannern and Luna 24 curves will be used to set the slow (Fig. 3A) and fast (Fig. 3B) bounds, respectively, on the rate estimates for Serocki lavas.
Walker et al. (1978) show the dependence of plagioclase texture on $\mathrm{T}_{\text {init }}$. By analogy with the Walker et al. results, plagioclase groundmass textures in Serocki lavas resemble those formed in cooling rate experiments where $T_{\text {init }}>$ plagioclase appearance temperature. The effect of cooling from $\mathrm{T}_{\text {init }}>$ plagioclase appearance temperature is to produce elongate and skeletal morphologies. The resemblance of Serocki plagioclase to plagioclase produced by cooling from superliquidus temperatures may be a consequence of the absence of sites for plagioclase nucleation, rather than a result of initial superheat in the erupted Serocki lavas (Lofgren, 1983). Although Serocki lavas contain 2-4 vol.\% phenocrysts of plagioclase and olivine, the plagioclase is An-rich $\left(\mathrm{An}_{84}\right)$ and not in equilibrium with the Serocki liquid. The liquidus plagioclase at $1 \mathrm{~atm}$ in Serocki lavas is $\mathrm{An}_{72-69}$ (Grove et al., this volume). Therefore, Serocki lavas may have been erupted with a small degree of superheat. Our rate estimates below attempt to account for this possibility. 


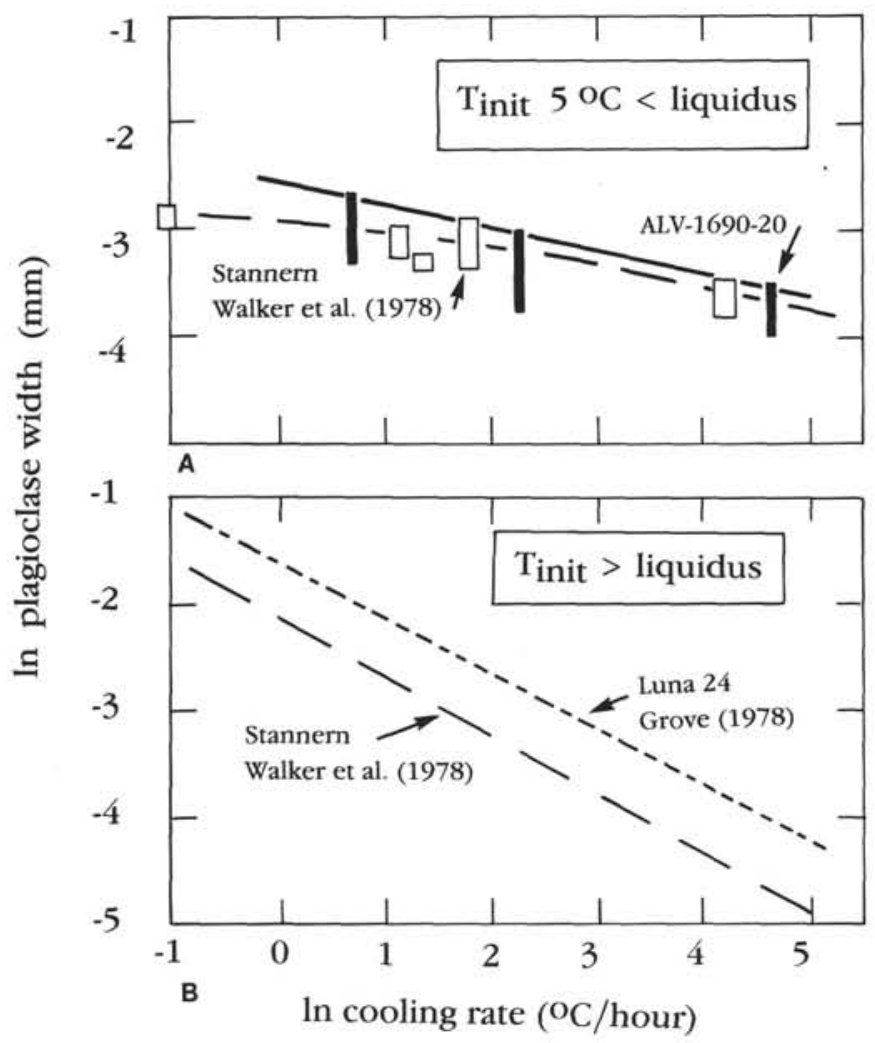

Figure 3. Dependence of plagioclase size on cooling rate in Serocki cooling rate experiments and other natural compositions for which plagioclase is a liquidus or near liquidus phase. A. Size range of plagioclase in Serocki cooling rate experiments (dark solid bars) cooled from $10^{\circ}-14^{\circ} \mathrm{C}$ below liquidus. Open boxes are sizes of plagioclase produced in cooling rate experiments on the eucrite meteorite Stannern initiated $5^{\circ} \mathrm{C}$ below the liquidus. B. Dependence of plagioclase size on cooling rate in cooling rate experiments on Luna 24 ferrobasalt and Stannern initiated at $5^{\circ} \mathrm{C}$ or greater above the liquidus.

\section{ESTIMATION OF COOLING RATE FOR SEROCKI LAVA}

Cooling rates for the Serocki lavas were estimated using both the ALV-1690-20 results (Fig. 3A) and the Grove (1978) (Fig. 3B) curves, and the estimates are tabulated in Table 2. The Figure 3A curve is applicable if Serocki lavas cooled from $\mathrm{T}_{\text {init }}<$ liquidus, and the Figure 3B curve is assumed to estimate cooling rate for $T_{\text {init }}>$ liquidus. The two estimates provide minimum and maximum cooling rates, respectively. To use these rate estimates to infer magma body sizes present in Serocki volcano, some simplifying assumptions must be made. It is assumed that the crystal's growth records an in situ event, and that there has been no movement of the crystal relative to a boundary of heat loss during cooling at the seafloor. Thus, it is assumed that there has been no crystal settling or flotation, and that no transport of the crystal by magma movement has occurred. With these simplifications in mind, the expression of Jaeger (1957, Eq. 13) was used. This expression relates distance from a boundary of conductive heat loss and cooling rate recorded over a part of the solidification interval. The resulting estimates infer a maximum half-width for cooling units in Serocki volcano. The maximum half-widths estimated using this method are on the order of $0.2-3.0 \mathrm{~m}$ for the lower massive portion of the Hole $648 \mathrm{~B}$ core.

\section{ESTIMATION OF COOLING RATES FOR BASALTS FROM DSDP HOLE 396B}

Kirkpatrick and Hodges (1978) made quantitative textural measurements in a thick cooling unit from Core 396B-15 which sampled 235-245.5 m sub-bottom depth. Based on the assumption that recovery is proportional to total penetration below seafloor, the cooling unit was about $9 \mathrm{~m}$ thick and sampled a lava flow or shallow sill. Their measure of plagioclase size perpendicular to $(010)$ is directly comparable to our measurements, and shows a maximum size of $0.38 \mathrm{~mm}$ at maximum. The bulk composition of this Hole 396B lava is similar to our Serocki lava, and a comparison of cooling rates is therefore justified. Cooling rate inferred from plagioclase size would estimate a half-width for the Core 396B-15 cooling unit of 1.5-4 m, comparable to that inferred from reconstruction of flow thickness by Kirkpatrick and Hodges (1978).

\section{SUMMARY}

Groundmass textures in Serocki lavas are consistent with cooling at the seafloor from an initial temperature slightly above the liquidus. This conclusion is in contrast to the one that would be drawn from the presence of a plagioclase + olivine phenocryst assemblage, which would be that the Serocki lava was saturated with these phases upon eruption. However, many of the plagioclase phenocrysts are An-rich $\left(\mathrm{An}_{84}\right)$, and are not in equilibrium with Serocki lava. The equilibrium Serocki liquidus plagioclase is $\mathrm{An}_{72}$. Therefore, Serocki lavas may have been erupted at a temperature slightly above their 1-atm liquidus containing xenocrysts of plagioclase.

Cooling rates estimated from textures indicate a maximum flow thickness of $6 \mathrm{~m}$ from the $1.2 \mathrm{~m}$ of returned core. Core recovery in Hole 648B was poor, and adjacent pieces of core could be from widely separated positions in the cored interval. Our analysis of textural size variation in Core 648B-15R, which advanced $10.8 \mathrm{~m}$ and recovered $1.2 \mathrm{~m}$ of basalt, provides an example of the problems associated with poor recovery. In the worst case, Core 648B-15R could have penetrated two flows. The lowermost massive basalt unit was estimated to be about $17.5 \mathrm{~m}$ in thickness from drilling operations. Sample 648B-18R-1, 32-34 cm, was chosen from this lower massive unit because it appeared to be the sample with the coarsest textures and hence slowest cooling rate. This sample cooled in a flow of estimated to be $5.8 \mathrm{~m}$ thick. If the core from the lowermost massive unit has provided a representative sample of the stratigraphy, there must be two or more lava cooling units present.

\section{ACKNOWLEDGMENTS}

This research was supported by NSF OCE-8609961. S. Recca expertly maintained the MIT electron microprobe facility. I thank $\mathrm{T}$. Juster and R. Kinzler and two anonymous reviewers for reviews.

\section{REFERENCES}

Biggar, G. M., 1972. Diopside, lithium metasilicate and the 1968 temperature scale. Mineral. Mag., 38:768-770.

Bryan, W. B., 1972. Morphology of quench crystals in submarine basalts. J. Geophys. Res., 77:5812-5819.

Cashman, K. V., and Marsh, B. D., 1984. Crystal-size spectra and kinetics of crystal growth in magma: II. Application. Geol. Soc. Am. Abstracts with Programs, 6:465. (Abstract).

Grove, T. L., 1978. Cooling histories of Luna 24 very low Ti (VLT) ferrobasalts: An experimental study. Proc. Lunar Planet. Sci. Conf. 9 th, 565-584.

1981. Use of FePt alloys to eliminate the iron loss problem in 1 atmosphere gas mixing experiments: Theoretical and practical considerations. Contrib. Mineral. Petrol., 78:298-304. 
Grove, T. L., and Walker, D., 1977. Cooling histories of Apollo 15 quartz-normative basalts. Proc. Lunar Sci. Conf. 8th, 1501-1520.

Humphris, S. E., Bryan, W. B., and ODP Leg 106/109 Scientific Parties. 1986. Anatomy of Serocki volcano. Trans. Am. Geophys. $U ., 44: 1213-1214$. (Abstract).

Jaeger, J. C., 1957. The temperature in the neighborhood of a cooling intrusive sheet. Am. J. Sci., 255:306-318.

Kirkpatrick, R. J, 1978. Processes of crystallization in pillow basalts, Hole 396B, DSDP Leg 46. In Dmitriev, L., Heirtzler, J., et al., Init. Repts. DSDP, 46: Washington (U.S. Govt. Printing Office), 271-282.

Kirkpatrick R. J., and Hodges, F. N., 1978. Crystallization of the Core 15 basalt cooling unit, Hole 396B, DSDP Leg 46. In Dmitriev, L., Heirtzler, J., et al., Init. Repts. DSDP, 46: Washington (U.S. Govt. Printing Office), 259-269.

Lofgren, G. E., 1980. Experimental studies on the dynamic crystallization of silicate melts. In Hargraves, R.B. (Ed.), Physics of Magmatic Processes: Princeton (Princeton Univ. Press), 487-551. 1983. Effects of heterogeneous nucleation on basaltic textures: A dynamic crystallization study. J. Petrol., 24:229-255.

Lofgren, G. E., Grove, T. L., Brown, R. W., and Smith, D. P., 1979. Comparison of dynamic crystallization techniques on Apollo 15 quartz normative basalts. Proc. Lunar Planet. Sci. Conf. 10th, 423-438.

Nabalek, P. I., Taylor, L. A., and Lofgren, G. E., 1978. Nucleation and growth of plagioclase and the development of textures in a high alumina basaltic melt. Proc. Lunar Planet. Sci. Conf. 9th, $725-741$.

Tormey, D. R., Grove, T. L., and Bryan, W. B., 1987. Experimental petrology of normal MORB near the Kane Fracture Zone: $22^{\circ}-25^{\circ} \mathrm{N}$, mid-Atlantic ridge. Contrib. Mineral. Petrol. 96: 121-139.

Walker, D., Longhi, J., Kirkpatrick, R. J., and Hays, J. F., 1976. Differentiation of an Apollo 12 picrite magma. Proc. Lunar Sci. Conf. 7th, 1365-1389.

Walker, D., Powell, M. A., Lofgren, G. E., and Hays, J. F., 1978. Dynamic crystallization of a eucrite basalt. Proc. Lunar Planet. Sci. Conf. 9th, 1369-1391.

Winkler, H.G.F, 1949. Crystallization of basaltic magma as recorded by variations of crystal size in dikes. Mineral. Mag., 28:557-574.

Date of initial receipt: 15 June 1988

Date of acceptance: 1 May 1989

Ms 106/109B-113 